\title{
Configuration of technology networks in the wind turbine industry. A comparative study of technology management models in European and Chinese lead firms
}

\author{
Haakonsson, Stine Jessen; Kirkegaard, Julia Kirch
}

Published in:

International Journal of Technology Management

Link to article, DOI:

10.1504/IJTM.2016.075892

Publication date:

2016

Document Version

Peer reviewed version

Link back to DTU Orbit

Citation (APA):

Haakonsson, S. J., \& Kirkegaard, J. K. (2016). Configuration of technology networks in the wind turbine industry. A comparative study of technology management models in European and Chinese lead firms. International Journal of Technology Management, 70(4), 281-299. https://doi.org/10.1504/IJTM.2016.075892

\section{General rights}

Copyright and moral rights for the publications made accessible in the public portal are retained by the authors and/or other copyright owners and it is a condition of accessing publications that users recognise and abide by the legal requirements associated with these rights.

- Users may download and print one copy of any publication from the public portal for the purpose of private study or research.

- You may not further distribute the material or use it for any profit-making activity or commercial gain

- You may freely distribute the URL identifying the publication in the public portal 


\section{A Comparative Study of Technology Management Models in European and Chinese Lead Firms}

\section{Stine Jessen Haakonsson and Julia Kirch Kirkegaard}

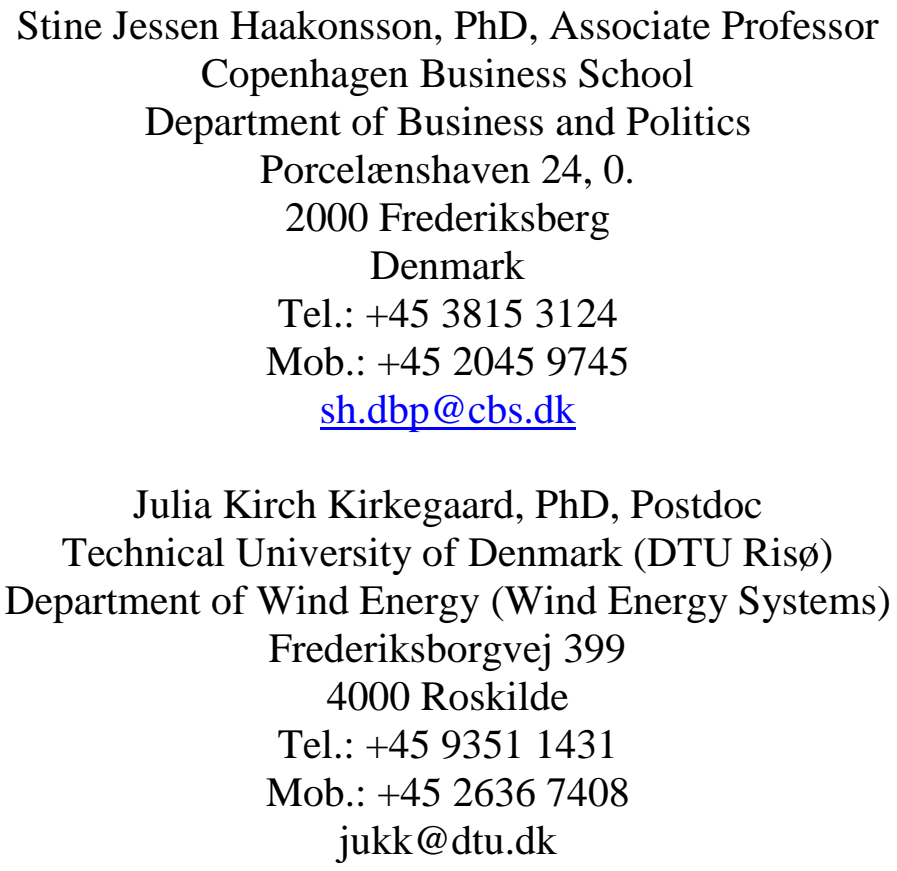

* This research project was kindly sponsored by the Sino-Danish Center for Research and Education (SDC)

Stine Jessen Haakonsson is Associate Professor at the Department of Business and Politics, Copenhagen Business School and Principal Coordinator for Social Science in the Sino-Danish Center for Research and Education. Stine holds a PhD in Economic Geography from the University of Copenhagen and the Danish Institute for International Studies. Her research is currently focused on the global restructuring of innovation into emerging global innovation networks and the role of emerging market actors in this process. Recently the focus has been on the globalisation of cleantech sectors, such as the wind turbine industry and bio-fuel, and the role of emerging market business actors in this process.

Julia Kirch Kirkegaard is Postdoc at the Department of Wind Energy (Wind Energy Systems), Technical University of Denmark (DTU Ris $\varnothing$ ). Julia holds a PhD from Copenhagen Business School (CBS) and Sino-Danish Centre for Research and Education (SDC) in Science-andTechnology-Studies, China-studies, and Global Innovation Networks. Julia has a background in China-studies, organisational sociology, and the anthropology of markets. Her current research focuses on the social and local acceptance of wind power in Denmark. 


\title{
Configuration of Technology Networks in the Wind Turbine Industry
}

\author{
A Comparative Study of Technology Management Models in \\ European and Chinese Lead Firms
}

\begin{abstract}
:
Through a comparative analysis of technology management at the component level by wind turbine manufacturers from Europe and China, this article compares strategies of internalisation of core technology components by European and Chinese lead firms and outlines how different internalisation strategies impact the networks established by the two types of lead firms. Building on the concept of governance developed by the global value chain literature, the article identifies two different types of networks: European lead firms internalise core technology components and keep strong captive or relational ties with key component suppliers, whereas Chinese lead firms modularise and externalise core technology components, hence adopting a more flexible approach to technology management. The latter model mirrors a strategy of overcoming technological barriers by tapping into knowledge through global innovation networks. The article contributes to the network governance literature by introducing scales of component technology complexity and lead firm capabilities for understanding network constructs.
\end{abstract}

\section{Key words:}

Global Innovation Networks, technology management, component technology, wind turbines, governance, lead firms strategies, technology complexity, Europe-China, internalisation, externalisation. 


\section{Introduction: Configuration of Technology and Innovation Networks in the Wind Turbine Industry}

Emerging market firms are increasingly developing into lead firms combining and managing technology from their home base as well as from abroad. For these firms to stay competitive, they need to manage new technologies that previously were not necessary and which emerging market lead firms do not themselves control the development of. In other words, they need to tap into knowledge and technology, and hence network strategies as the basis of technology management have become increasingly important for these firms. Over the past decade, lead firms from emerging markets, in particular China, have entered the global wind turbine manufacturing industry at a rapid pace. By 2012, four of the ten largest wind turbine manufacturers in the world were Chinese. Yet, there is little existing knowledge about how these new entrants manage technology as compared to the traditional Western lead firms. Chen et al. (2014) shows how these firms access technology through engaging in collaborative ties across geography, e.g. within China and globally (Chen et al., 2014; Lewis, 2013; Silva and Klagge, 2014; Kirkegaard, 2015), and Lema et al. (2011) have analysed the potential for collaboration between European and Chinese actors. Their studies show how the Chinese market has become a driver for reshaping the dynamics of the industry (Lema et al., 2011). However, there are still significant gaps in our knowledge about global innovation networks in this industry, their dynamics and the underlying different technology management strategies.

The aim of this article is to identify strategic drivers for technology management among lead firms from Europe and China and assess the consequences of the different technology management models. In order to understand the emerging networks, it is crucial to look beyond market and production activities and into corporate strategies for managing technology. As technology is often dispersed in the networks, we argue that there is a need to take in the complexity of technology and access to knowledge as well as capabilities as drivers of network constructions. Further, these drivers need to be understood at the component level, as the technological complexity varies among components and component suppliers in the network. To investigate the global restructuring of innovation into networks, the key questions addressed in this article are as follows: (1) What factors determine strategies of internalisation and externalisation of core technology components undertaken by European and Chinese lead firms? (2) How do different internalisation strategies impact governance structures of the technology networks established by the two types of lead firms?

So far, research and literature have largely analysed the European wind turbine industry and the global value chain for wind energy as seen from a Northern perspective (Karnøe and Buchhorn, 2010; Lema et al., 2011; Lema et al., 2013). Europe has traditionally played a lead role as an innovation hub in the development of modern wind turbines. Yet, Chinese actors within wind energy - along with Chinese energy policies generating a large domestic market for wind turbines have turned China into a key location for all actors in the industry (Lewis, 2013). In 2012, China had developed into the largest market in terms of installed capacity in wind turbines (Chen et al., 2014). By the early 2000s, European lead firms began targeting the Chinese markets through increased offshoring, firstly of the production of wind turbines and, secondly, also of core component production to and sourcing from China. These lead firms predominantly engage through outsourcing to component producers in China and increasingly by experimenting with relocation of research and development (R\&D) to China. Meanwhile, several Chinese wind turbine manufacturers have established R\&D activities in Europe through offshoring strategies (Lewis, 2013). 
The ongoing reconfiguration of the industry creates new dynamics and hence new types of lead firm strategies for technology management. Lead firms have developed global networks involving technology and innovation. Recently, the construction of such technology-related networks by lead firms across the world has been termed global innovation networks (Ernst, 2006; OECD, 2008; UNCTAD, 2005; Lall, 2000; Chaminade, 2009; Barnard and Chaminade, 2012; Cooke, 2013; Silva and Klagge, 2013; Parrilli et al., 2013). Global innovation networks are here defined as globally organised networks of interconnected and integrated functions and operations by firms and nonfirm organisations engaged in the development and diffusion of technology and innovation. The global innovation networks literature draws (among other things) on the global value chain framework focusing on how lead firms evolve into orchestrators of dispersed production activities across space. More recently also innovation processes are moving beyond the scope of individual companies and their national innovation systems (Cantwell and Zhang, 2011). Accordingly, in order to stay competitive lead firms need to actively tap into networks of knowledge creation as part of their innovation strategies to sustain market access (Chesbrough, 2003; Fagerberg et al., 2005; Prahalad and Khrisnan, 2008; Archibugi and Lundvall, 2001; Amin and Cohendet, 2005). The empirical evidence of global innovation networks is both limited and contested and so far very little attention has been given to the consequences this development has for how technology is managed. Likewise are the consequences at the firm level in terms of how this affects technology management models and their outcome.

In order to understand the characteristics of these new network constructs, and how technology is managed in these, a central concept from the global value chain literature, governance, will be applied (Gereffi et al., 2005). By understanding governance as coordination, i.e. the type of relationship between actors along the value chain, this literature offers a typology for analysing how technology is coordinated through different types of relationships within and between network actors. Hence, the coordination of technology at the component level is an identifier of lead firms' technology management strategies and capabilities in regard to degrees of complexity of different components. The current literature on internationalisation of technology largely ignores the scales of technology complexity in components from the outset and its role in the configuration of networks and governance structures.

Moreover, acknowledging that products can be highly complex, consisting of a large number of more or less technology-intensive components, which in turn may encompass technologies from a range of sectoral innovation systems, component technology complexity should be added to the analytical framework. The complexity of each component potentially impacts governance structures and hence network configuration. Focusing on technological complexity at the component level combined with an investigation of the technological trajectories of lead firms allows for an analysis of how these factors may influence technology management models.

In the following section, the literature is reviewed with a specific focus on the concept of governance relating this to scales of component technology complexity. Section 3 presents the methodology, herein the empirical data collection and the conceptualisation and operationalisation of the analysis. Section 4 presents the background, the emergence of a global wind turbine industry and the contextualisation of this. The analysis in section 5 is a comparison of the technological management models employed by European and Chinese lead firms with different types of technology trajectories. This leads to a discussion on the implications for governance structures of the different network constructs. This lays the foundation for the conclusion. 


\section{Integrating Governance Modes with Strategies of Technology Management}

The global value chain approach was first developed in the early 1990s for analysing the global restructuring of production due to economic globalisation (Gereffi et al., 2005; Gereffi, 1994). Others have identified the global (re)configuration of value chains into networks where internationalisation of production is integrated with internationalisation of innovation (Chaminade and Vang, 2008). In these approaches, the global restructuring of production is generally understood as a process, within which the capacity to produce and export manufactured goods is increasingly dispersed to an expanding network of peripheral and core nations (Gereffi et al., 1994; Feenstra, 1998; Dicken, 2007). Gereffi (1994: 96) described this global restructuring in the following terms: 'economic activity is not only international in scope; it is also global in its organisation'. The main contribution here is its focus on relationships between actors and in particular on how various types of relations impact industrial and technological upgrading in emerging markets (Humphrey and Schmitz, 2004; Gibbon, 2005; Sturgeon et al., 2008).

In order to compare different types of technology management models, to lay the foundation for an understanding of different network configurations, the concept of governance is relevant. Governance is here understood as the coordination of component suppliers by lead firms and reflects the degree of power asymmetry between lead firms and suppliers, and the transaction costs of externalisation of production and/or technology. The typology of governance is based on three dimensions: 1) complexity of transactions, 2) the ability to codify transactions, and 3) the capabilities found in the supply base (Gereffi et al., 2005). Where there are low transaction costs, activities will be externalised through market-based relations and, at the other end of the continuum, with high transaction costs, activities will be internalised through vertical integration (hierarchical) (ibid.). In between full externalisation and internalisation, captive, relational and modular forms of network governance can be identified according to complexity, codifiability and capabilities (see Figure 1).

Although the global value chain approach is well established, the focus remains on the chains through which products are produced, leaving out flows of innovation, technology and knowledge, and how these flows are managed by the lead firms through coordination based on the complexity, codifiability and capabilities and the technology complexity of components involved in the relationship (e.g. if the component is core, semi-core or non-core). Global value chain research mainly focuses at chains in which upstream activities are located in the global South and the downstream segments close to the market in the global North. However, as the global South develops, local customers emerge. Within wind turbines this certainly is the case. Consequently, new networks have emerged that are likely to follow different dynamics according to the technological capabilities contained in the South-based lead firm. Hence, networks can be created in-house across locations or with external partners. Moreover, in case of lacking technological capacity, lead firms may manage their technology through networks by which they access complex component technology not available in-house.

Over the past decade, technology management moved from managing activities taking place predominantly within companies to globally organised innovation networks including actors outside the company. Most innovation involving external actors takes place in collaboration with suppliers and customers, i.e. upstream and downstream collaboration in the value chain, but research 
institutions, government institutions, and universities, are increasingly relevant actors for innovation as well. These external actors may be dispersed globally, consequently leading to the internationalisation of technology management (Cantwell and Zhang, 2011). Internationalisation of innovation as lead firm strategy is seen to have several stages: from knowledge exploitation, i.e. selling products developed at home in new markets, through a process where the company increasingly adjusts the products to the new markets and initiates collaboration with local 'expertise' on the market, to end up as true knowledge augmenting or exploring strategies where the company taps into capabilities abroad that are complementary to what they have in-house and in their home national innovation system (Kuemmerle, 1999; Archibughi and Michie, 1995; March, 1991; Cantwell and Iammarino, 2003). Linking this to the concept of governance, the exploitation stage would lead to internalisation of complex components or restricted captive relationships in which the capabilities remain with the lead firm engaging in the relationship, while modular and relational relationships with component suppliers link more with collaboration and explorative, augmenting strategies in the lead firms.

Moreover, it is important to identify ways to include the component technology complexity and issues on access to technology, knowledge, and innovation into understanding global restructuring of technology and innovation and the impact of innovation network configuration for different types of lead firms (e.g. their capabilities and complexity of technology). In order to understand the link with the capabilities of the lead firm, we combine the global value chain approach with a strategic view on technologies, applying concepts from the resource-based view of the firm (Barney, 1991; Teece et al., 1997; Peteraf, 1993). According to the resource-based view, when resources are valuable, imperfectly imitable and imperfectly substitutable, they constitute a core competence to the firm and should be protected (Barney, 1991; Peteraf, 1993), e.g. by 'black-boxing' it through IPR-protection and/or keeping it in-house or tightly governing it in a captive relationship (Peteraf, 1993). Due to their strategic importance, component technologies of high complexity will be more heavily controlled, governed and hence protected as they constitute the core competence of the lead firm vis-à-vis the component supplier. As we will see later, lead firms tend to hand over control to suppliers when 1) the component is non-core or 2) when they do not have in-house capabilities related to high component technology complexity. As regards lead firms from emerging markets, however, these late-comer firms instead seem to take advantage of their own resource deficiency: by pursuing a considerate strategy of tapping into the resources of foreign firms in the developed economies, which are imitable and transferable resources, these late-comer firms reverse the resource-based view (Mathews, 2002). That is, they pursue a Linkage, Leverage, and Learning strategy (Mathews, 2002). Overall, component complexity and/or firm capabilities determine the type of governance relations and technology management model lead firms choose for their networks.

\section{Please insert Figure 1 about here}

By looking into strategically important components and the component technologies involved in the design and production of a wind turbine, we can understand how lead firms - based on their technological resources and capabilities as well as on the complexity of components - establish different governance relations. That is, the internal technological capabilities as well as the different levels of component technology complexity determine the type of technology management strategy as well as the governance type. Figure 1 illustrates the conceptual connection between lead firm strategies of technology management, technology complexity, firm capabilities, and governance mode. 


\section{Methodology}

The comparative study is based on firm and expert interviews conducted in Denmark, Germany, and China (Beijing, Shanghai, Hangzhou, Suzhou, and Chengdu) supplemented by secondary sources on wind energy policies, firm strategies etc. The empirical data was collected between 2011 and 2014 in Denmark and China through 34 semi-structured interviews among six Chinese and two European lead firms, and 15 component (five Chinese and ten European) suppliers with different levels of component technology complexity. Expert interviews were carried out among Danish (DTU(Ris $\varnothing)$ ) and Chinese research institutes (CASTED, CAS), and industrial associations for wind power in Europe and China. Among the eight lead firms interviewed five are among the ten largest wind turbine manufacturers in the world. From each lead firm between two and five strategic managers, innovation managers, and engineers were interviewed. For the companies present in Europe and China, managers at both locations were interviewed. All the component suppliers were interviewed in China and some also in Europe. All interviews lasted one to two hours and were often followed up by informal discussions afterwards. In addition to interviews, participatory observations and informal interviews with technology component suppliers were conducted during five large conference fairs for wind turbines - three in China, one in Germany and one in Denmark. Interviews have been transcribed, and we have coded the data along the variables of 1) firm capabilities, 2) governance mode, 3) component complexity, and 4) technology management model.

We categorise component suppliers according to the technology complexity of the components produced. This 'decomposition' of the wind turbine into different component complexity levels has been done in collaboration with engineers from the leading research centre on wind energy in Denmark, the Technical University of Denmark (DTU(Ris $\emptyset)$ ). A wind turbine contains about 10,000 different components of a very different nature, with different degrees of complexity of transaction and codifiability. The different types of technology needed in the wind turbine industry crosses a range of different traditional technology sectors, such as IT/software for controllers (e.g. pitch control of blades, grid connection) and simulation tools in design technologies, auto industry (gears and brakes), design and aerodynamics (blades), and machinery (generators and bearings). Therefore, in the analysis, we classify the wind turbine components into core, semi-core, and noncore components.

Core components are strategically important and technologically sophisticated, while non-core components are less important and contain basic technology. Core components are defined as strategic components, which directly determine the functioning and efficiency of the turbine (e.g. blades, generators, power converters, controllers). These components are complex and not easily codified, often relying also on tacit knowledge. As regards semi-core components, these display relatively low complexity and more possibilities for codification. Lastly, non-core components are easily codified and simple and can be traded with relatively few transaction costs. An example of a systemically important core component is the software part of the control system technologies of the wind turbine - or, what may be the 'brain' or 'spine' of the wind turbine. These e.g. contain software codes and algorithms e.g. for pitching the blades. Semi-core components are more easily codifiable, yet still highly specialised components (towers, brakes, hydraulic systems, gearboxes). Lastly, examples of non-core components are: bearings, shafts, casting, and other often low-tech and widely available, components, which are also used in other industries, which are characterised by low complexity and high codifiability. 


\section{The Changing Geography of the Wind Turbine Industry}

The development of the wind turbine industry and, with it, the European lead firms, began in the 1970s and was primarily developed on the basis of a strong collaborative Danish national innovation network for wind energy and supportive domestic policies in the 1980s (Edquist, 2008; Karnøe and Buchhorn, 2010). On this basis, a unique innovation system was established based on large testing facilities and long track records for the quality of wind turbines - with core competencies within the establishment of wind farms (including aerodynamics, minimising power loss in energy transmission, wind mapping, and other wind turbine installation-related technologies) and within the use and design of wind turbines. This has turned Denmark in particular and Europe in general into a global hub for innovation in wind energy. With increased specialisation over time, the European industry has experienced a consolidation of actors: so there are relatively few but large wind turbine manufacturers in Europe. The largest ones are Vestas, Siemens, Gamesa and Enercon.

Recently, the dominant position of European lead firms has been challenged by the rise of Chinese lead firms. Embedded in a Chinese supportive institutional framework, of which especially the Renewable Energy Law (2005/2006, revised 2009; Government of China, 2005; 2009), recent fiveyear plans, and innovation strategies play the most important role, Chinese actors have increased their production and technological capabilities within wind energy (Chen et al., 2014; Slepniov et al., 2015). In the period around 2006 to 2011, growth rates were rising rapidly, and China turned into a high priority investment area for Western lead firms (Lewis, 2007; Karnøe and Buchhorn, 2010; Globalwind, 2009). During the same period, the number of wind turbine manufacturers increased rapidly, boasting around 80 wind turbine manufacturers in China. Currently, four Chinese manufacturers are in the top ten global wind turbine manufacturers (Sinovel, Goldwind, Guodian United, and Mingyang) (BTM, 2012).

Nevertheless, most of the dominant Chinese manufacturers have emerged since 2006 along with the issuing of supportive policies. Prior to this, the Chinese industry evolved largely from donors, acquisition of finished wind turbines, imitation, reverse engineering, licensing, and assistance from foreign consultants (Chen et al., 2014; Lema et al., 2011; Lewis 2007, Lewis, 2013; Kirkegaard, 2015; Klagge et al., 2013; Silva and Klagge, 2014,). Despite high ambitions in terms of developing innovative capabilities, Chinese lead firms still lag behind in terms of developing and designing wind turbines and core components indigenously. Lacking capabilities for obtaining international certification for most of the European market, Chinese wind turbine manufacturers still produce almost exclusively for the domestic market. Recently, severe quality and grid connection issues have emerged in the industry along with heavy competition between the many new wind turbine manufacturers resulting in a current consolidation phase. Among other things, this has resulted in the introduction of a number of industry and technology standards by the Chinese Government (Kirkegaard, 2015; Korsnes, 2014).

Overall, there are significant differences in terms of technological capabilities between the European and Chinese wind turbine manufacturers and component suppliers, since Chinese lead firms are still lagging behind in terms of in-house technology performance related to quality and core components. 


\section{Comparative Analysis of Technology Management Models}

Having set the context and background of European and Chinese lead firms and their capabilities, the following offers a comparative analysis of the dominant technology management models of the two types of lead firms. This provides a basis for the subsequent discussion of governance modes.

\subsection{European lead firms: Exploitation by sourcing from the selected few}

European lead firms generally see the wind turbine as an integrated system consisting of interdependent technology components. The integrated systemic features of the wind turbine and interconnectedness of components for efficiency are integral to the reliability and competitiveness of the turbines. One manager explains how the core component of e.g. control system software represents the 'spine' of the wind turbine: "When you get the whole way down through the different layers of source codes, you finally get down to where the core algorithm is. This core algorithm binds together all the information from the different parts" (interview, manager). Thus, a high degree of adjustment and co-development of different components is needed to enhance the efficiency and lifetime of the wind turbine. Since externalisation of core components and design activities would incur high transaction costs, European lead firms have internalised production of almost all core and semi-core components both in Europe and in China.

In Table I in Appendix A, this vertical integration of core components by two European lead firms - Vestas and Siemens - is illustrated. Looking at one type of core component, generators for instance, it is clear that European lead firms source these in-house. However, when a lead firm has no competence or occasionally not enough production capacity, e.g. for generators or blades, European lead firms may choose to source core components from highly specialised European suppliers that have established in China, instead of producing them in-house. So far, core component suppliers are all of European origin. For most foreign lead firms, FDI is a full package investment that includes assisting specialised suppliers' entry into China.

As regards a semi-core component such as towers, this component is the most localised component in the wind turbine value chain for onshore installations and can be produced by most companies with a heavy industry background. As regards non-core components, e.g. bearings, these components are generally more widely available and can be bought almost at the spot market. European lead firms do use Chinese suppliers, but only for semi-core- and non-core components, and based on direct technical specifications, standards, and certification requirements. As expressed by one manager: "Some suppliers have been committed for a long time. I know some suppliers are also our colleagues or from high school or something. It is a close network. And actually we have official meetings every year" (interview, European lead firm). Hereby, semi-core components are produced by suppliers with whom the lead firms have long-term captive relationships or exclusive contractual arrangements. Likewise, one of the European lead firms states that "as a general trend, we are trying to localise as much as it makes sense, in terms of quality and safety" (interview, manager). This indicates that European lead firms are concerned about the quality of the final products and hence need to keep control of the value chain. In order to ensure turbine quality when sourcing components externally, European lead firms buy from certified suppliers exclusively: "We are not even comparing the quality. We use certified suppliers, we do not pick up the cheaper suppliers. Only certified" (interview, manager, European lead firm). 
The higher the component technology complexity and internal capabilities of producing the component, the more internal control is pursued by European lead firms. This technology integration - preserving the firm's core competence - is seen as a major competitive asset by these firms. When not containing component production and development within the boundaries of the firm, European lead firms seek to minimise transaction costs. For semi-core or non-core components, this takes place without exploring joint development of core components. We can thus see how European lead firms are pursuing an exploitation strategy in terms of their technology management model when engaging in relations with suppliers.

\subsection{Chinese lead firms: Exploration by flexible sourcing}

Although in a process of establishing themselves as emerging multinationals, Chinese lead firms have so far remained technology followers. Chinese wind turbines are in general basic, and many core components are sourced from foreign suppliers. This is due to lack of experience, capabilities, and of a strong national innovation network. Nevertheless, during the past decade, Chinese lead firms have built basic know-how in certain component technologies (primarily semi- and non-core), and wind turbine design, and they are working intensively on developing indigenous Chinese turbines.

Looking into the sourcing of different core components, Table II in Appendix A displays how most Chinese lead firms source core components from leading foreign technology component suppliers. Chinese lead firms have a broader variety of suppliers than the European lead firms. For instance in the case of the core component of generators, these are often sourced through diverse suppliers, but at other times sourced through a one-to-one relationship of co-creation between the lead firm and the specialised suppliers (interview). As regards the sourcing of blades, one Chinese lead firm explains that they have chosen to use a European specialised supplier for collaboration on blade development. This lead firm has built a blade production and development facility to their supplier near their production site: "We built up a facility for them near our facility and rent it to [the foreign company]. They can very quickly move and they are very satisfied with our deal. It is a winwin" (interview, manager, Chinese lead firm). Another Chinese lead firm explains that they are engaged in close collaboration with a Chinese blade supplier - having sourced from a Danish blade company initially. This shift is explained by a strategy to sharpen competition and reduce costs: "We have a very close collaboration. We are developing a blade where we do the design of the aerodynamics, the entire geometrical work on the blade. The Chinese supplier designs the structure of the blade" (interview, manager, Chinese lead firm). Since Chinese companies are increasingly involved in blade production, Chinese lead firms increasingly choose to source from Chinese suppliers. At the same time, sourcing of blades is often not a one-to-one relationship - several lead firms buy the same type of blade from the same supplier, and each may have several suppliers for the same type of component: "How many suppliers for the blades? Each part we should have at least three suppliers also for the blades" (interview, manager, Chinese lead firm). Finally, some lead firms have blade production in-house. Yet, none of the Chinese lead firms have internalised more than a few core components. Hereby, large state-owned Chinese lead firms tend to have "the largest supplier network ever seen" (manager, European component supplier). Even for core components, Chinese wind turbine manufacturers 'share' suppliers: "Most large suppliers are also our suppliers. We discuss, we tell them our requirements and our planning. We share suppliers with others, sometimes our knowledge is open. [...] We have many suppliers, so also for me I cannot identify which one is our main supplier. We have long-term agreements with suppliers" (interviews, managers, Chinese lead firms). 
A last example of a core component is software programs for controllers (in particular for main control and pitch control), which is a technologically complex component. As expressed by one Chinese turbine manufacturer: "it is very easy to make the hardware right, but the software is more complicated. We can also make software, but we do not have much experience. So we are looking for short cuts" (interview, manager, Chinese lead firm). Short cuts mean buying technology core components from European suppliers. As expressed by another Chinese company: "We are working on the control systems, also have some suppliers. The pitch system, we buy it from other suppliers foreign. We import it" (interview, manager, Chinese lead firm). Largely dependent on foreign control system software - consisting basically of myriads of lines of algorithmic codes based on long-term basic research and development, know-how, experience, and testing - this core component is not easily tapped into. To overcome this technological gap, Chinese lead firms seek to engage in different types of collaborations with foreign suppliers and universities. This they do in what we may call emerging global innovation networks. Hereby, they use their resource deficiency to tap into resources of other firms, pursuing a strategy of linkage, leverage, and learning.

As regards semi-core and non-core components, along with Chinese lead firms who are mainly involved in the assembly of components into the wind turbine end-product, there exists a forest of Chinese and foreign suppliers. This is e.g. the case for semi-core components such as towers and gearboxes: "Towers are outsourced. Most components are produced in China today" (interview, manager, Chinese lead firm). For these components, Chinese wind turbine manufacturers tend to have a list of different suppliers to choose from: "For each component we have at least three suppliers. For standard ones one or two is enough" (interview, manager, Chinese lead firm). "It is not hard to get these components - they are available [...] Initially almost half of the parts [were] from abroad, now it is almost all local." This technology management model spurs price competition among suppliers; i.e., for "cost efficiency we have built up a supplier pool in China [...] we always [have] more than one supplier for example gearbox etc., we have two or three. To supply on competitive price" (interviews, managers, Chinese lead firms).

Although a Chinese lead firm has adopted a technology management model of sourcing core components exclusively from high-tech suppliers, primarily European lead firms - in order to brand itself as high quality rather than low cost - there is a gradual shift towards using Chinese suppliers. This shift takes place as the capabilities of Chinese suppliers are rising. Still, however, lagging behind in terms of highly complex technology components, Chinese lead firms have chosen to pursue an open, flexible, and networked technology management model based on exploration. The Chinese exploration strategy can be seen as a necessary and innovative approach to overcome their lack of technological capabilities and counter the costly 'technology-containing' exploitation strategy of European lead firms. We hereby see traits of emerging global innovation networks, in particular as the Chinese lead firms seek to link up, leverage, and learn from tapping into external resources.

\section{Governance Modes: Integration and Captive Control or Flexible Modularity}

What we have seen from decomposing the wind turbine is that the level of component complexity together with supplier and lead firm capabilities - has an impact on the technology management model. Overall, Chinese lead firms tend to source core technology components more than European 
lead firms. We will now move on to a discussion of how the different technology management models impact governance structures.

European lead firms have a high degree of vertical integration of both production and innovation activities with many core components produced and developed in-house; they are vertically integrated through hierarchical governance structures. At other times, when developing core components in collaboration in networks, this takes place with carefully selected suppliers some of which have high capabilities, indicating a relational or captive governance mode. As regards semicore and non-core components, relationships with suppliers are characterised by relational (e.g. when suppliers with high level of capabilities are carefully selected and based on long-term relationships), captive (e.g. when produced by specific requirements from the lead firm), modular, and market (e.g. when technically simple components can be bought almost at the spot market) relationships in accordance with the level of complexity, codifiability, and the capabilities of the suppliers.

In contrast, rather than fully integrating core components, Chinese lead firms have a more modular chain configuration than we saw with the European lead firms. As regards semi-core and non-core components, relations are predominantly market-based. Hereby, most Chinese lead firms are de facto assembly companies with limited in-house production of a few core components and sourcing from suppliers through supplier networks. "The Chinese producers are more like assembly companies, they don't have full control of everything" (interview, manager, European component supplier). This is supported by two other Chinese lead firms: "Only one part we manufacture ourselves - that is the generator magnet motors [...] our core competence is assembly" and - apart from blades - it is "just assembly here, the components are from the suppliers" (interviews, managers, Chinese lead firms).

\section{Please insert Figure 2 about here}

These different governance modes - depending on component technology complexity - are depicted in the model above. In addition, the variation in governance mode relates to a great diversity in the capabilities of suppliers.

As regards the Chinese technology management model and governance mode, this relates to what Mathews (2002) has termed 'linkage-leverage-learning', or of 'assimilation and absorption'. As was put by a Chinese lead firm: "Links abroad are good for innovation. Linkages are important for learning" (interview, manager, Chinese component supplier). Historically based on foreign licences, Chinese lead firms have been engaged in heavy adaptation and reverse engineering. For instance, as was explained by a Chinese lead firm regarding brakes, "Germany provided the original technology. [The company] took the brake, cut it apart and found out how to produce it ourselves. We opened the black box" (interview, manager, Chinese lead firm). Additionally, regarding a Chinese lead firm sourcing control systems from a European supplier, the supplier expresses: "I don't think there is one single control system supplier in the world which has not delivered a prototype to them at some point in time. And then I'm sure that as soon as they have delivered a prototype for them, then they [Chinese lead firms] are splitting it apart and start analysing... and they are still working on this, they have not succeeded yet" (interview, manager, European component supplier). As Chinese lead firms lack the core competencies themselves, they 
access foreign knowledge through relations. As expressed by Chinese lead firms, "we need experiences from abroad, to learn [e.g.] from Denmark" or by another Chinese lead firm: "We always make collaboration specialised. We didn't do everything ourselves. We look for resources. Then we find out who is best... we go for "who is the expert"' (interview, manager). Also Chinese researchers and engineers go to foreign companies and abroad to learn about the specific technologies and ideas. "We have had collaboration with foreign companies for many years. If there is a chance, then go and learn" (interview, Chinese researcher).

Overall, the global value chain within the wind turbine industry is highly complex. Chinese lead firms source with a high degree of flexibility, being open for exploring ventures for learning. The Chinese companies - functioning more as assembly firms, sourcing core and semi-core components from foreign or local specialised component suppliers - have started from another outset than European lead firms, e.g. with less experience and technological capabilities. Hence, instead of focusing on systemic technology integration (and the basic research required), their core competence is the ability to engage in complex networks with multiple actors, or, in what we may term emerging global innovation networks. In short, due to the lack of in-house capabilities, Chinese lead firms rely on integration into global innovation networks as a core part of their technology management model. This contrasts with the picture of European lead firms for whom the core competence has been their control of complex component technologies and their appropriation. Due to their high capabilities they do not engage as actively in global innovation networks.

At the theoretical level, our analysis extends the comparative models of technology management to also include a new dimension, namely that of degrees of component technology complexity. This involves an understanding of the interplay of lead firm capabilities and technology complexity and how they influence technology management models and governance modes differently. On this basis, the global value chain approach would benefit from including the role of technologies at the component level in the configuration of governance relations. Adding to the codifiability dimension of the global value chain approach, we have indicated the need for decomposing complex products into different component levels, and thus indicating a new governance dimension of technology complexity. Additionally, further research should look into whether the different technology management models of European and Chinese lead firms are converging due to differing costs in the long and short term of different governance models as well as due to the Chinese lead firms building new capabilities. Lastly, further research should look into the impact of lead firm capabilities and component technology complexity on prospects for industrial upgrading.

\section{Conclusion}

This article conducts a comparative study of technology management models of European and Chinese lead firms, demonstrating how there are not only 'national' models, but also 'component technology models' within the wind turbine industry in China. Decomposing the wind turbine into different levels of component technology complexity, the analysis displays that whereas European lead firms tend to integrate components, containing their core technologies, and keeping strong relational ties with their key supplier(s), Chinese lead firms tend to modularise component technologies and source from highly specialised suppliers through modular relationships, thus adopting a more open and flexible approach. The technology management model employed by European lead firms is based on exploitation, whereas Chinese lead firms have employed a 
technology management model of exploration. This difference is based on differing lead firm and supplier capabilities. Chinese companies - functioning more as assembly firms, sourcing core and semi-core components from foreign or local specialised component suppliers - have started from another outset with less experience and technological capabilities. Exploring how a strategy of linkage, leverage, and learning can render access to external resources and technologies, the core competence of Chinese lead firms is the ability to engage in complex networks with multiple actors. We may term these configurations emerging global innovation networks. The article relates the different technology management models to different governance modes. Whereas European lead firms tend to internalise core components through vertical integration or govern them through relational coordination with key-suppliers, Chinese lead firms tend to engage in modular governance forms. As regards semi-core and non-core components, European lead firms tend to engage in more captive or market-based types of coordination whereas Chinese lead firms rely on market-based and modularised coordination.

The strategies for technology management undertaken by European and Chinese lead firms depend on the level of lead firm (and supplier) capabilities and component technology complexity. Further, the strategies for technology management result in different governance structures, i.e. different types of networks by the two types of lead firms, the former more captive and exploitative, whereas the latter is more flexible and explorative. Hence, we suggest that in order to understand different technology management models across space, component technology complexity should be added as a determining factor for the governance relations in the value chain. 


\section{List of References}

Amin, A. and Cohendet, P. (2005) 'Geographies of knowledge formation in firms', Industry and Innovation, Vol. 12 No. 4, pp.465-86.

Archibugi, D. and Lundvall, B. A. (2001) The Globalising Learning Economy: Major Socioeconomic Trends and European Innovation Policy, Oxford University Press, Oxford.

Archibugi, D. and Michie, J. (1995) 'The globalisation of technology: a new taxonomy', Cambridge Journal of Economics, Vol. 19, pp. 121-40.

Barnard, H. and Chaminade, C. (2011) 'Global Innovation Networks: what are they and where can we find them? (Conceptual and Empirical issues)'. INGINEUS Paper for Globelics, Buenos Aires, Nov. 2011. Argentina.

Barney, J. (1991) 'Firm resources and sustained competitive advantage', Journal of Management, Vol. 17 No. 1, pp. 99-120.

BTM Consult (2011) International Wind Energy Development: World Market Update 2011 Forecast 2012-2016. Navigant Research.

BTM Consult (2013) World Market Update 2012. International Wind Energy Development. Forecast 2013-2017. Navigant Research.

Cantwell, J. and Zhang, Y. (2011) 'Innovation and location in the multinational firm', International Journal of Technology Management, Vol. 54 No. 1, pp.116-32.

Cantwell, J. and Iammariono, S. (2003): Multinational Corporations and European Regional Systems of Innovation, Routledge, London.

Chaminade, C. (2009) 'On the concept of Global Innovation Networks', Working paper. CIRCLE, Lund University, Lund, Sweden.

Chaminade, C. and Vang, J. (2008) 'Globalisation of knowledge production and regional innovation policy: Supporting specialized hubs in the Bangalore software industry', Research Policy, Vol. 37, pp.1684-96.

Chen, Y., Rong, K., Xue, L. and Luo, L. (2014) 'Evolution of Collaborative Innovation Network in China's wind turbine manufacturing industry' International Journal of Technology Management, Vol 65 No. 1, pp. 262-99.

Chesbrough, H. W. (2003) Open Innovation: The New Imperative for Creating and Profiting from Technology, Harvard Business School Press, Boston.

Cooke, P. (2013): 'Global Production Networks and Global Innovation Networks: Stability Versus Growth'. European Planning Studies, Vol. 21, No. 7, pp. 1081-1094.

Dicken, P. (2007) Global Shift: Mapping the Changing Contours of the World Economy, 5th edition, Sage, London.

Edquist, C., and Holmen, L. (2008) Small Country Innovation Systems. Globalization, Change and Policy in Asia and Europe, Edward Elgar, Cheltenham.

Ernst, D. (2006) 'Innovation offshoring. Asias's emerging role in Global Innovation Networks', East-West Center Special Reports, No. 10.

Feenstra, R. C. (1998) 'Integration of trade and disintegration of production in the global economy', Journal of Economic Perspectives, Vol. 12 No. 4, pp. 31-50.

Gereffi, G. (1994) 'The organization of buyer-driven global commodity chains: how US retailers shape overseas production networks', in Gereffi, G. and Korzeniewicz, M. (eds) Commodity Chains and Global Capitalism, Greenwood Press, Westport CT.

Gereffi, G., Humphrey, J. and Sturgeon, T. (2005) 'The Governance of Value Chains', Review of International Political Economy, Vol. 12 No. 1, pp.78-104. 
Gibbon, P. (2005) 'Governance, entry barriers, upgrading: a re-interpretation of some GVC concepts from the experience of African garment exports', paper presented to Global Commodity Chains and Global Value Chains conference, Yale University, May 2005. Globalwind (2009) Globalwind 2009 Report, Global Wind Energy Council (GWEC).

Government of China (2005) 'Renewable Energy Law' Standing Committee of the National People's Congress (NPC) http://www.ccchina.gov.cn (accessed 16 January 2014).

Government of China (2007) 'Medium and long-term development plan for renewable energy in China.' National Development and Reform Commission. http://www.chinaenvironmentallaw.com/wp-content/uploads/2008/04/medium-and-longterm-development-plan-for-renewable-energy.pdf (accessed 16 January 2014).

Humphrey, J. and Schmitz, H. (2000) 'Governance and upgrading: Linking industrial cluster and global value chain research', IDS Working Paper 120.

Humphrey, J. and Schmitz, H. (2004) 'Chain governance and upgrading: Taking stock', in Schmitz, H. (ed.) Local Enterprises in the Global Economy, Edward Elgar, Cheltenham.

Karnøe, P. and Buchhorn, A. (2010) 'Denmark: Path-creation dynamics and winds of change', in Lafferty, W. M. and Ruud, A. (eds) Promoting Sustainable Electricity in Europe:

Challenging the Path Dependence of Dominant Energy Systems, Edward Elgar Publishing, Cheltenham, pp. 73-101.

Kirkegaard, J. K. (2015) 'Ambiguous winds of change - or fighting against windmills in China wind power. A constructivist inquiry into China's pragmatics of green marketization. Mapping controversies over a potential turn to quality in Chinese wind power'. 1 st ed., $P h D$ Series 05-2015.

Klagge, B, Liu, Z., and Silva, P. C. (2012): 'Constructing China's wind energy innovation system'. Energy Policy, Vol. 50, pp. 370-382.

Korsnes, M. (2014): 'Fragmentation, Centralisation and Policy Learning: An Example from China's Wind Industry'. Journal of Current Chinese Affairs, Vol. 43, No. 3, pp. 175-205.

Kuemmerle, W. (1999) 'The drivers of foreign direct investment into research and development: An empirical investigation', Journal of International Business Studies, Vol. 30 No.1, pp.1-24.

Lall, S. (2000) 'Technological change and industrialization in the Asian newly industrializing economies: Achievements and challenges', in Kim, L. and Nelson, R. R. (eds.) Technology, Learning and Innovation. Experience of Newly Industrializing Economies, Cambridge University Press, Cambridge.

Lema, R., Berger, A., Schmitz, H., and Song, H. (2011) 'Competition and cooperation between Europe and China in the wind power sector', Institute of Development Studies (IDS) Working Paper, Vol. 2011 No. 377.

Lema, R., Berger, A., and Schmitz, H. (2013) 'China's impact on the global wind power industry', Journal of Current Chinese Affairs, Vol. 42 No. 1, pp. 37-69.

Lewis, J. I. (2007) 'Technology acquisition and innovation in the developing world: Wind turbine development in China and India', Studies in Comparative and International Development, Vol. 42, pp. 208-32.

Lewis, J. I. (2013) Green Innovation in China. Columbia University Press, New York.

March, J. G. (1991) 'Exploration and exploitation in organizational learning', Organization Science, Vol. 2 No. 1, Special Issue: Organizational Learning: Papers in Honor of (and by) James G. March. (1991), pp. 71-87.

Mathews, J. A. (2002) 'Competitive advantages of the latecomer firm: A resource-based account of industrial catch-up strategies’, Asia Pacific Journal of Management, Vol. 19, pp. 467-88. 
Morrison, A., Pietrobelli, C., and Rabellotti, R. (2008) 'Global value chains and technological capabilities: A Framework to study learning and innovation in developing countries', Oxford Development Studies, Vol. 36 No. 1, pp.39-58.

OECD (2008) 'The economics of climate change', preparation of the 4-5 June 2008 council meeting at ministerial level. C(2008)60.

Parrilli, M. D., Nadvi, J., and Yeung, H. W.-C. (2013): 'Local and Regional Development in Global Value Chains, Production Networks and Innovation Networks: A Comparative Review and the Challenges for Future Research'. European Planning Studies, Vol. 21, No. 7, pp. 967-988.

Peteraf, M.A. (1993) 'The cornerstones of competitive advantage: A resource-based view', StrategicManagement Journal, Vol. 14 No. 3, pp.179-91.

Prahalad, C. K. and Khrisna, M. S (2008) The New Age of Innovation: Driving Co-created Value through Global Networks. McGrawHill, New York.

Silva, P. C. and Klagge, B. (2013) 'The Evolution of the Wind Industry and the Rise of Chinese Firms: From Industrial Policies to Global Innovation Networks', European Planning Studies, Vol. 21, No. 9, pp. 1341-1356.

Slepniov, D., Lassen, A.H., Haakonsson, S.J., and McKelvey, M. (2015) 'Understanding innovation spaces through emerging multinational enterprises in China: an explorative case study of a Chinese wind turbine manufacturer', in McKelvey, M. and Bagchi-Sen, S. (eds.) Innovation Spaces in Asia. Entrepreneurs, Multinational Enterprises and Policy, Edward Elgar, Cheltenham.

Sturgeon, T. J., van Biesebroeck, J., and Gereffi, G. (2008) 'Value chains, networks and clusters: reframing the global automotive industry', Journal of Economic Geography, Vol. 8, pp. 297321.

UNCTAD, 2005. World Investment Report - Transnational Corporations and the Internationalization of $R \& D$. UNCTAD, New York and Geneva. 
Figure 1: Lead firm technology control: A taxonomy of technological component complexity

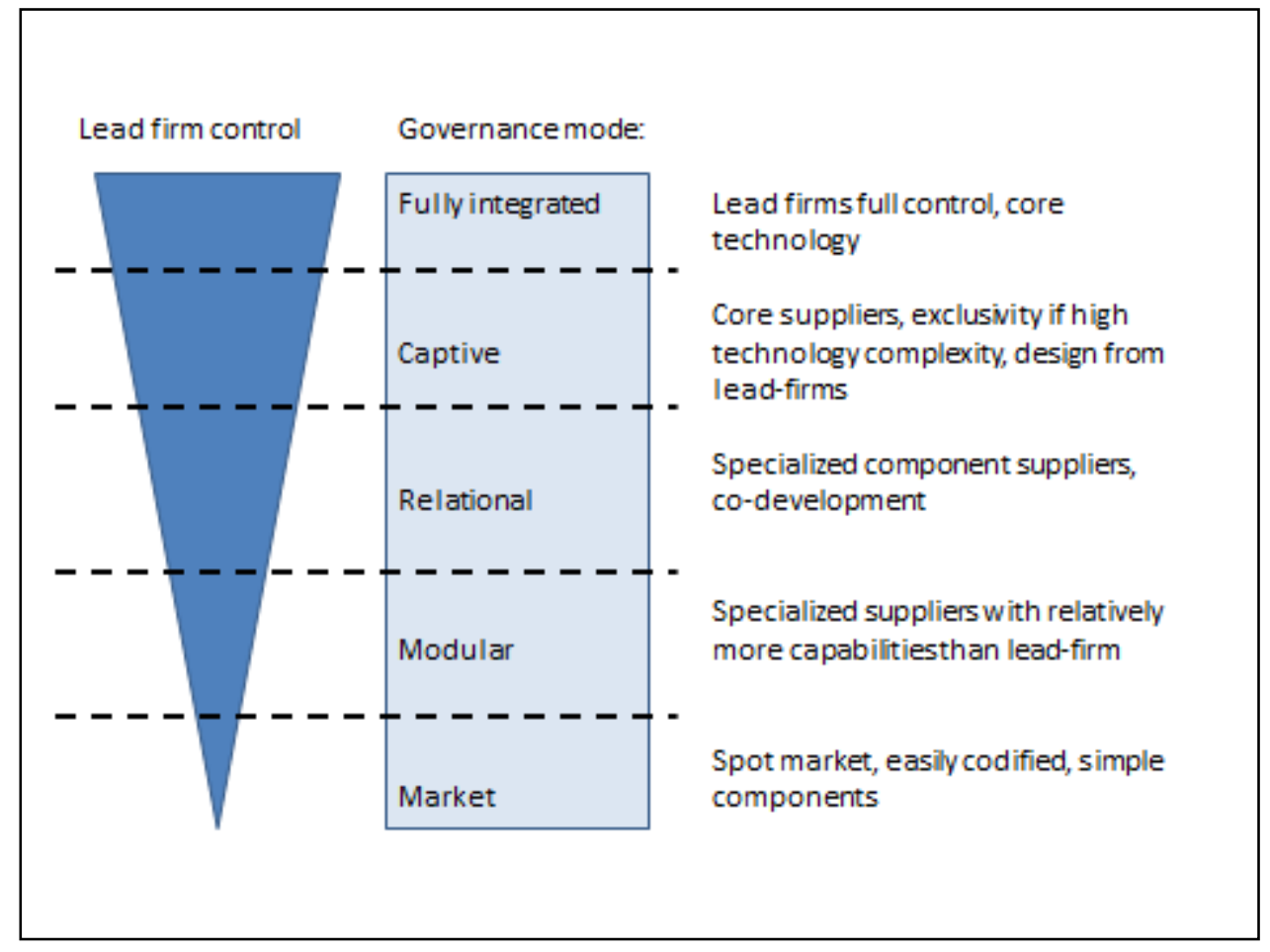

Figure 2: Comparison of European and Chinese technology management models

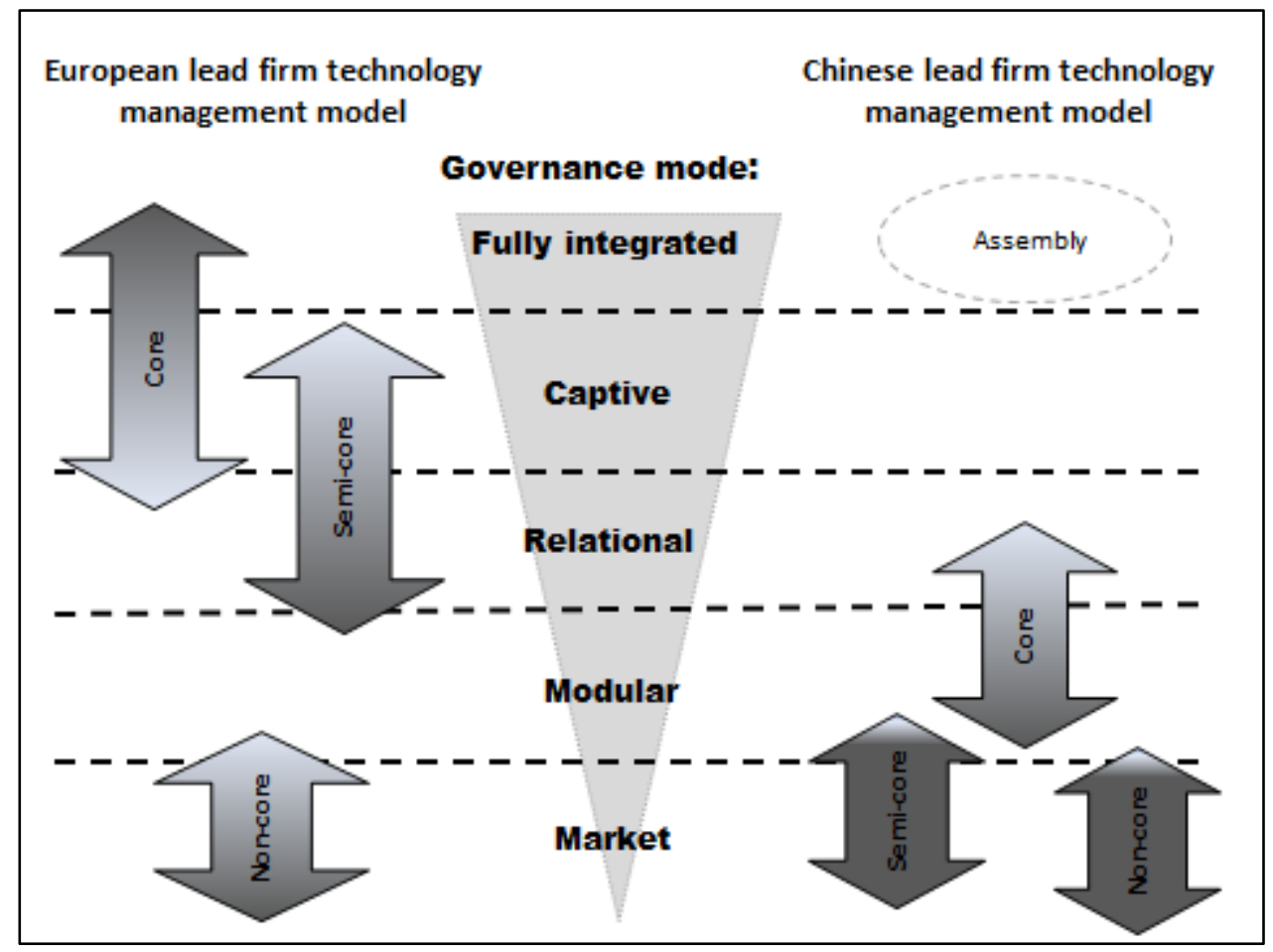




\section{Appendix A}

Table I: European lead firms and their suppliers of core components

\begin{tabular}{|l|l|l|l|l|}
\hline & Blades & $\begin{array}{l}\text { Generato } \\
\text { rs }\end{array}$ & Controllers & Power Converters* \\
\hline \multirow{4}{*}{ Vestas } & Vestas (99\%) & Vestas & Vestas (Cotas) & Vestas \\
\cline { 2 - 5 } & LM (in China) & Elin & $\begin{array}{l}\text { NEG } \\
\text { (Dancontrol) }\end{array}$ & General Atomics \\
\cline { 2 - 5 } & & ABB & & \\
\cline { 2 - 5 } & & $\begin{array}{l}\text { LeroySom } \\
\text { er }\end{array}$ & & \\
\cline { 2 - 5 } Siemens & Siemens (93\%) & Siemens & Siemens & Siemens \\
\cline { 2 - 5 } & & Winergy & KK-Electric & Converteam \\
\cline { 2 - 5 } & & ABB & & Winergy \\
\cline { 2 - 5 } & & $\begin{array}{l}\text { Convertea } \\
\mathrm{m}\end{array}$ & & \\
\hline
\end{tabular}

Source: BTM, 2011.

Table II: Chinese firms and their suppliers of a-components

\begin{tabular}{|c|c|c|c|c|}
\hline & Blades & Generators & Controllers & $\begin{array}{l}\text { Power } \\
\text { converters* }\end{array}$ \\
\hline \multirow[t]{6}{*}{ Sinovel } & $\begin{array}{l}\text { Zhongfu } \\
\text { Lianzhong }\end{array}$ & Yongji & $\begin{array}{l}\text { Dalian Guotong } \\
\text { Electric }\end{array}$ & Sinovel \\
\hline & Huiteng & Tianyuan & & Emerson \\
\hline & LM & Elin & & \\
\hline & Aeolon & LeroySomer & & \\
\hline & Kunshan Huafeng & $\begin{array}{l}\text { Jiamusi } \\
\text { Electric }\end{array}$ & & \\
\hline & & WUXI SEC & & \\
\hline \multirow[t]{6}{*}{ Goldwind } & Goldwind (33\%) & CSR Zhuzhou & $\begin{array}{l}\text { Beijing Techwin } \\
\text { Electric }\end{array}$ & Goldwind \\
\hline & LM & Yongji & & $\mathrm{ABB}$ \\
\hline & Huiteng & Nanqi & & The Switch \\
\hline & Sinoma & XAWPCW & & Freqcon \\
\hline & $\begin{array}{l}\text { Zhongfu } \\
\text { Lianzhong }\end{array}$ & A-TECH & & Vacon \\
\hline & & Goldwind & & \\
\hline \multirow[t]{4}{*}{ Dongfang } & Dongfang $(50 \%)$ & Dongfang & DEIF & Dongfang \\
\hline & Aeolon & Yongji & Mita Technic & The Switch \\
\hline & $\begin{array}{l}\text { Zhongfu } \\
\text { Lianzhong }\end{array}$ & $\begin{array}{l}\text { XEMC: } \\
\text { DFEM }\end{array}$ & Forward & Converteam \\
\hline & Sino-wind Energy & $\begin{array}{l}\text { Lanzhou } \\
\text { Electric }\end{array}$ & & Hopewind \\
\hline
\end{tabular}




\begin{tabular}{|c|c|c|c|c|}
\hline & & & & Sungrow \\
\hline \multirow{5}{*}{$\begin{array}{l}\text { United } \\
\text { Power }\end{array}$} & United Power & United Power & Beckholf & United Power \\
\hline & $\begin{array}{l}\text { China Energy WP } \\
\text { Equipment }\end{array}$ & XEMC & United Power & $\mathrm{ABB}$ \\
\hline & Aeolon & $\begin{array}{l}\text { Nanjing } \\
\text { Turbine }\end{array}$ & & Beijing Corona \\
\hline & & VEM & & Woodward \\
\hline & & & & Emerson \\
\hline \multirow[t]{2}{*}{ Mingyang } & Mingyang & $\begin{array}{l}\text { Nanjing } \\
\text { Turbine }\end{array}$ & REnergy Electric & \\
\hline & Sinoma & S. Nanyang & & \\
\hline \multirow[t]{4}{*}{ Sewind } & $\begin{array}{l}\text { Zhongfu } \\
\text { Lianzhong }\end{array}$ & SEC & SE Power T\&D Group & \\
\hline & Shanghai FRP & $\begin{array}{l}\text { CSIC } \\
\text { Electrical }\end{array}$ & Mita Technic & \\
\hline & Dawntine & $\begin{array}{l}\text { Nanjing } \\
\text { Turbine }\end{array}$ & & \\
\hline & & $\begin{array}{l}\text { Lanzhou } \\
\text { Electric }\end{array}$ & & \\
\hline
\end{tabular}

Source: BTM, 2011. 